\title{
ストレプトマイシン使用者の平衡機能検査
}

(Jumbling 症例の Vestibular Compensation について)

$$
\begin{aligned}
& \text { 桜 井 敏 恵・中 井 義 明 - 山 根 英 雄 } \\
& \text { 小 西 一 少妙 中 啓 子 }
\end{aligned}
$$

\section{Equilibrium Function Test in Patients Treated with Streptomycin}

\author{
Toshie Sakurai, Yosiaki Nakai, Hideo Yamane, \\ Kazuo Konishi and Keiko Taenaka \\ (Osaka City University)
}

Among 68 patients treated with streptomycin sulfate (SM) 7 with the jumbling phenomenon (JP) showed severe bilateral vestibular dysfunction. Five of them were followed for long periods to investigate the recovery of body equilibrium, which we call vestibular compensation (VC).

The results of vestibular function tests of these patients were compared with those of patients with unilateral dead labyrinth due to C-P angle tumor or its surgical treatment.

The patients with unilateral dead labyrinth showed good recovery of body equilibrium with eyes either open or closed. On the otherhand, in the patients with bilateral vestibular injury we could not recognize any improvement of body balance, and the center of gravity was never within the confidence limit.

These result suggest one labyrinth is necessary for completing $\mathrm{VG}$, even though its function is partial.

\section{緒言}

Jumbling 現象は両側高度前庭機能低下もしくは, 喪失時に出現する身体頭部動摇視及び固視障 害で1)2)，1941年 Dandy が初めて報告している. 本邦では, 1967年以降, アミノ配糖体系抗生剂に よる内耳障害との関連で, 種々の報告が行われている. 今回我々は, 硫酸ストレプトマイシン（以 下 SM と略す)使用者に対して, 定期的に平衡機能検查を施行し，その結果 Jumbling 7 症例を経 験した. この 7 症例中, 5 症例について経過観察を行いVestibular compensation の有無につい て，若干の知見を得たので，文献的考察を加えて報告する.

\section{対象及び方法}

昭和 58 年 4 月から昭和 59 年 12 月にかけて, 大 阪市立大学附属病院結核病棟で $\mathrm{SM}$ 投与中の 68名（男性50名，女性18名）を対象として定期
的に平衡機能検査, 純音聴力検査を施行した. 初回検査は可能なかぎり, SM 使用前に行い, $\mathrm{SM}$ 使用中は約 1ケ月拈きに施行した。各自に 
蝸牛症状, 前庭症状の有無を問診し, その後, 立ち直り検査 (Romberg, Mann, 単脚起立), 足踏及検查 (100歩), 重心動摇検査, 温度眼振

結

対象となった 68 名中の年令性別は表 1 の如く で，全例に损いて INH，RFP を併用してお り, SM 平均投与量は $41.3 \mathrm{~g}$ であった. $\mathrm{SM}$ 投 与量により全例を 5 群にわけ自覚症状及び検查 結果と SM 投与量との関連について検討した. (I 群: SM 投与量 $1-20 \mathrm{~g}$, II 群: SM 投与 量21-40 g, III群: SM 投与量 $41-60 \mathrm{~g}$, IV群 : SM 投与量61-80 g, V 群 : SM 投与量81$100 \mathrm{~g})$

\section{1) 自覚症状（表 2)}

68名中約半数の 30 名が，なんらかの自覚症状 を有しており, そのらち4名が耳鳴を, 19名が 立ちくらみ, 浮遊感, フラフラ感を訴兄てお り, 7 名に Jumbling 症状が見られた. しかし， これらの自覚症状は Jumbling 症状以外は SM

表 1 年令分布

\begin{tabular}{|c|c|c|c|c|c|c|c|}
\hline & $10-20$ t & $21-30$ 才 & $31-40$ 才 & $41-50$ 才 & $51-60$ 才 & $61-70$ 才 & $71-80$ 才 \\
\hline 男性 & 6 & 3 & 6 & 9 & 13 & 9 & 4 \\
\hline 女性 & 3 & 6 & 2 & 1 & 2 & 3 & 1 \\
\hline 計 & 9 & 9 & 8 & 10 & 15 & 12 & 5 \\
\hline
\end{tabular}

表 $2 \mathrm{~S} \mathrm{M}$ 投与量と自覚症状

\begin{tabular}{|c|c|c|c|c|c|}
\hline 自筧应状 & $\begin{array}{c}\mathrm{I} \\
(10-20 \mathrm{~g})\end{array}$ & $\begin{array}{c}\text { II } \\
(21-40 \mathrm{~g})\end{array}$ & $\begin{array}{c}\text { III } \\
(41-60 \mathrm{~g})\end{array}$ & $\begin{array}{c}\mathrm{N} \\
(61-80 \mathrm{~g})\end{array}$ & $\begin{array}{c}\mathrm{V} \\
(81-100 \mathrm{~g})\end{array}$ \\
\hline & 2 & 1 & 1 & 0 & 0 \\
\hline 立ちくらみ & 1 & 0 & 3 & 2 & 1 \\
\hline 浮 功 感 & 2 & 6 & 2 & 1 & 0 \\
\hline ふらふら感 & 0 & 0 & 0 & 1 & 0 \\
\hline Jumbling & 5 & 1 & 1 & 0 & 0 \\
\hline 自党症状なし & 10 & 5 & 9 & 10 & 4 \\
\hline 計 & 20 & 13 & 16 & 14 & 5 \\
\hline
\end{tabular}

検査 $\left(20^{\circ} \mathrm{C} 50 \mathrm{ml} 30\right.$ 秒間注水法, もしくは $4^{\circ} \mathrm{C}$ $20 \mathrm{ml}$ 10秒間注水法）を施行した.

果

投与終了後 $2-3$ ケ月でほぼ完全に消失してい る. SM 投与量と自覚症状の間には特に関連は 認められなかった. 又 Jumbling 症状がみられ た症例の SM 投与量は各及, $5 \mathrm{~g}, 6 \mathrm{~g}, 9.75$ $\mathrm{g}, 10.5 \mathrm{~g}, 17 \mathrm{~g}, 22.5 \mathrm{~g}, 45 \mathrm{~g}$ であった.

2 ）立ち直り検查（表 3 ）偏奇検査（表 4)

立ち直り検查として Romberg (両脚起立), Mann 単脚起立検查を行い, 下肢の偏奇検査と して足踏及検査（100歩）を施行した，立ち直 り検査の結果は表 3 の如くで, I 群は, Romberg 陽性例 7 名 (35\%), Mann 検查陽性例 8 名 (40\%), 単脚起立検査 8 名 (40\%) であった.

II 群では Romberg 検查陽性例 2 名 (15\%), Mann 検查陽性例 4 名 (30\%), 単脚起立検査陽

表 $3 \mathrm{~S} \mathrm{M}$ 投与量と立ち直り検査

\begin{tabular}{|c|c|c|c|c|c|c|}
\hline \multicolumn{2}{|c|}{ SM投与 } & $(0-20)$ & $\underset{(21-40)}{\text { II }}$ & $\underset{(41-60)}{\text { III }}$ & $\underset{(61-80)}{N}$ & $\underset{(81-100)}{\mathrm{V}}$ \\
\hline \multirow{2}{*}{ Romberg } & 正 常 & $\begin{array}{c}13 \\
(65 \%)\end{array}$ & $\begin{array}{c}11 \\
(84 \%)\end{array}$ & $\begin{array}{c}15 \\
(88 \%) \\
\end{array}$ & $\begin{array}{c}13 \\
(92 \%)\end{array}$ & $\begin{array}{c}5 \\
(100 \%)\end{array}$ \\
\hline & 異 常 & $\begin{array}{c}7 \\
(35 \%)\end{array}$ & $\begin{array}{c}2 \\
(15 \%)\end{array}$ & $\begin{array}{c}2 \\
(12 \%)\end{array}$ & $\begin{array}{c}1 \\
(7 \%)\end{array}$ & 0 \\
\hline \multirow{2}{*}{ Mann } & 正 常 & $\begin{array}{c}12 \\
(60 \%)\end{array}$ & $\begin{array}{c}9 \\
(69 \%)\end{array}$ & $\begin{array}{c}15 \\
(88 \%)\end{array}$ & $\begin{array}{c}13 \\
(92 \%)\end{array}$ & $\begin{array}{c}5 \\
(100 \%)\end{array}$ \\
\hline & 翼 常 & $\begin{array}{c}8 \\
(40 \%)\end{array}$ & $\begin{array}{c}4 \\
(30 \%)\end{array}$ & $\begin{array}{c}2 \\
(12 \%)\end{array}$ & $\begin{array}{c}1 \\
(7 \%)\end{array}$ & 0 \\
\hline \multirow{2}{*}{ 単脚起立 } & 正 常 & $\begin{array}{c}12 \\
(60 \%)\end{array}$ & $\begin{array}{c}8 \\
(61 \%)\end{array}$ & $\begin{array}{c}15 \\
(88 \%)\end{array}$ & $\begin{array}{c}13 \\
(92 \%) \\
\end{array}$ & $\begin{array}{c}5 \\
(100 \%) \\
\end{array}$ \\
\hline & 異 常 & $\begin{array}{c}8 \\
(40 \%)\end{array}$ & $\begin{array}{c}5 \\
(38 \%)\end{array}$ & $\begin{array}{c}2 \\
(12 \%)\end{array}$ & $\begin{array}{c}1 \\
(7 \%)\end{array}$ & 0 \\
\hline
\end{tabular}

表 $4 \mathrm{~S} \mathrm{M}$ 投与量と足踏み検査

\begin{tabular}{|c|c|c|c|c|c|}
\hline$\underbrace{\text { SM投与量 }}_{\text {足踏蔟查 }}$ & $\underset{(0-20 g)}{I}$ & $\begin{array}{c}\text { II } \\
(21-40 \mathrm{E})\end{array}$ & $\underset{(41-60 \mathrm{~g})}{\text { III }}$ & $\underset{(61-80 \mathrm{~g})}{\mathrm{N}}$ & $\underset{(81-100 \mathrm{~g})}{\mathrm{V}}$ \\
\hline 正 常 & $\begin{array}{c}14 \\
(70 \%)\end{array}$ & $\begin{array}{c}6 \\
(46 \%)\end{array}$ & $\begin{array}{c}10 \\
(62.5 \%)\end{array}$ & $\begin{array}{c}11 \\
(78.5 \%)\end{array}$ & $\begin{array}{c}5 \\
(100 \%)\end{array}$ \\
\hline 異 常 & $\begin{array}{c}6 \\
(30 \%)\end{array}$ & $\begin{array}{c}7 \\
(54 \%)\end{array}$ & $\begin{array}{c}6 \\
(37.5 \%)\end{array}$ & $\begin{array}{c}3 \\
(21.5 \%)\end{array}$ & 0 \\
\hline
\end{tabular}


表 $5 \mathrm{~S} \mathrm{M}$ 投与量と重心動摇検査

\begin{tabular}{|c|c|c|c|c|c|c|c|c|c|c|c|c|c|c|c|c|}
\hline & \multicolumn{3}{|c|}{ 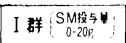 } & \multicolumn{3}{|c|}{ II 群 $\underset{21-10 \mathrm{~g}}{\mathrm{SM}}$} & \multicolumn{3}{|c|}{ III群! SM投与 } & \multicolumn{3}{|c|}{ N 群 $\begin{array}{c}S M 195 \\
61-808\end{array}$} & \multicolumn{3}{|c|}{ 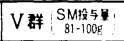 } \\
\hline & & $\begin{array}{l}\text { 前 } \\
\text { 後 } \\
\text { 慟 } \\
\text { 摇 }\end{array}$ & $\begin{array}{l}\text { 左 } \\
\text { 乭 } \\
\text { 摇 }\end{array}$ & $\begin{array}{l}\text { 動 } \\
\text { 摇 } \\
\text { 面 } \\
\text { 積 }\end{array}$ & $\begin{array}{l}\text { 前 } \\
\text { 後 } \\
\text { 播 } \\
\text { 摇 }\end{array}$ & $\begin{array}{l}\text { 左 } \\
\text { 䃨 } \\
\text { 摇 }\end{array}$ & \begin{tabular}{|l} 
峳 \\
摇 \\
面 \\
㱴
\end{tabular} & $\begin{array}{l}\text { 前 } \\
\text { 後 } \\
\text { 摇 } \\
\end{array}$ & $\begin{array}{l}\text { 左 } \\
\text { 乭 } \\
\text { 摇 }\end{array}$ & $\begin{array}{l}\text { 動 } \\
\text { 摇 } \\
\text { 面 }\end{array}$ & $\begin{array}{l}\text { 前 } \\
\text { 後 } \\
\text { 動 } \\
\text { 摇 } \\
\end{array}$ & $\begin{array}{l}\text { 左 } \\
\text { 䃆 } \\
\text { 摇 }\end{array}$ & $\begin{array}{l}\text { 憅 } \\
\text { 摇 } \\
\text { 面聙 }\end{array}$ & $\begin{array}{l}\text { 前 } \\
\text { 後 } \\
\text { 摇 }\end{array}$ & $\begin{array}{l}\text { 左 } \\
\text { 覔 } \\
\text { 摇 }\end{array}$ & $\begin{array}{l}\text { 動 } \\
\text { 摇 } \\
\text { 面 } \\
\text { 積 }\end{array}$ \\
\hline \multirow{4}{*}{$\begin{array}{l}\text { 開 } \\
\text { 眼 }\end{array}$} & 信頼限界を & 7 & 1 & 3 & 3 & 3 & 3 & 6 & 2 & 0 & 7 & 3 & 0 & 3 & 3 & 3 \\
\hline & 越えるもの & (35) & (5) & (15) & (23) & (23) & (23) & (37) & (12) & $(0)$ & $(50)$ & (21) & $(0)$ & $(60)$ & $(60)$ & $(60)$ \\
\hline & 衺却限界を & 7 & 7 & 11 & 7 & 9 & 9 & 6 & 12 & 14 & 3 & 9 & 9 & 0 & 0 & 0 \\
\hline & 越えるもの & (35) & (35) & (55) & $(53)$ & (69) & (69) & (37) & (75) & (87) & (12) & (64) & $(64)$ & $(0)$ & $(0)$ & $(0)$ \\
\hline \multirow{4}{*}{$\begin{array}{l}\text { 閉 } \\
\text { 眼 }\end{array}$} & 信頼限界を & 3 & 4 & 2 & 5 & 2 & 3 & 4 & 2 & 2 & 2 & 0 & 0 & 4 & 4 & 4 \\
\hline & 越えるもの & (15) & (20) & (10) & (38) & (15) & (23) & (25) & (12.5) & $(12.5)$ & (14) & $(0)$ & $(0)$ & $(80)$ & $(80)$ & $(80)$ \\
\hline & 棄却限界を & 10 & 10 & 13 & 8 & 11 & 10 & 9 & 13 & 13 & 8 & 10 & 10 & 0 & 0 & 0 \\
\hline & 越えるもの & (50) & (50) & (65) & (61) & (84) & (76) & (56) & $(81.2)$ & $(81.2)$ & (57) & (71) & (71) & $(0)$ & $(0)$ & $(0)$ \\
\hline
\end{tabular}

表 6 両側前庭機能高度低下症例（ストレプトマイシン投与による）

\begin{tabular}{|c|c|c|c|c|c|c|}
\hline $\begin{array}{l}\text { Number of } \\
\text { cases }\end{array}$ & age & sex & $\begin{array}{l}\text { Time to } \\
\text { occure Jumbling } \\
\text { phenomenon }\end{array}$ & $\begin{array}{l}\text { Total dose } \\
\text { of SM }\end{array}$ & \multicolumn{2}{|l|}{$\begin{array}{l}\text { OKN Pre- } \\
\text { Jumbling }\end{array}$} \\
\hline 1 & 64 & $\delta$ & 1 week & $45 \mathrm{~g}$ & $\mathrm{~N}$ \\
\hline 2 & 67 & $\delta$ & 5 days & $5 \mathrm{~g}$ & $\mathrm{~N}$ \\
\hline 3 & 65 & $\delta$ & 30 days & $22.5 \mathrm{~g}$ & $\mathrm{~N}$ & $\mathrm{~N}$ \\
\hline 4 & 50 & $\delta$ & 13 days & $9.75 \mathrm{~g}$ & $\mathrm{~N}$ & $\mathrm{~N}$ \\
\hline 5 & 29 & $\wp$ & 17 days & $17 \mathrm{~g}$ & $\mathrm{~N}$ \\
\hline
\end{tabular}

$N$ : normal

性例 5 名 (38\%), III群では Romberg 検查陽 性例 2 名 (12\%), Mann 検查陽性例 2 名（12 $\%$ ), 単脚起立検査陽性例 2 名（12\%）であっ た. IV群では Romberg 検査陽性例 1 名（7 $\%)$, Mann 検查陽性例 1 名 (7\%), 単脚起立 検査陽性例 1 名（7\%）でV群では，立ち直り 検査に異常を示した症例はなかったＩＩＩI III群 中で立ち直り検查に異常を示す症例が比較的多 く見られた。
足踏み検査の結果は表 4 の如くで異常所見を 示したものは I 群 6 名 (30\%)，II群 7 名 (54 $\%)$, III群 6 名 (37.5\%), IV群 3 名 (21.5\%), $\mathrm{V}$ 群 7 名 (54\%) でその大部分は, 移行距離の 異常であった。

\section{3 ) 重心動摇検査（表 5 ）}

表 5 に示したように，I群からV群において $\mathrm{SM}$ 投与量となんら関係なく, 動摇面積, 前後 動摇, 左右動摇が棄却限界をこえる異常値を示 
しており，閉眼時に増強する傾向が見られた。

4 ) 温度眼振検査 (図 1)

温度眼振検查は $20^{\circ} \mathrm{C} 50 \mathrm{ml} 30$ 秒間注水法を 行い温度眼振反応のパラメーターには, 最大緩 徐相速度を用いて SM 投与量との関連を検討 した。結果は図 1 の如くで, 温度眼振反応の大
きさと SM 投与量の間には特に一定の関連は 見られなかった. $20^{\circ} \mathrm{C} 50 \mathrm{ml} 30$ 秒間注水法で 反応の見られない場合は ice water $\left(4{ }^{\circ} \mathrm{C} 20\right.$ $\mathrm{ml}$ 10秒間注水法）で再刺激を行い，無反応の 場合を前庭機能高度低下とし，反応が見られた 場合は前庭機能低下と判定した。 今回温度眼振

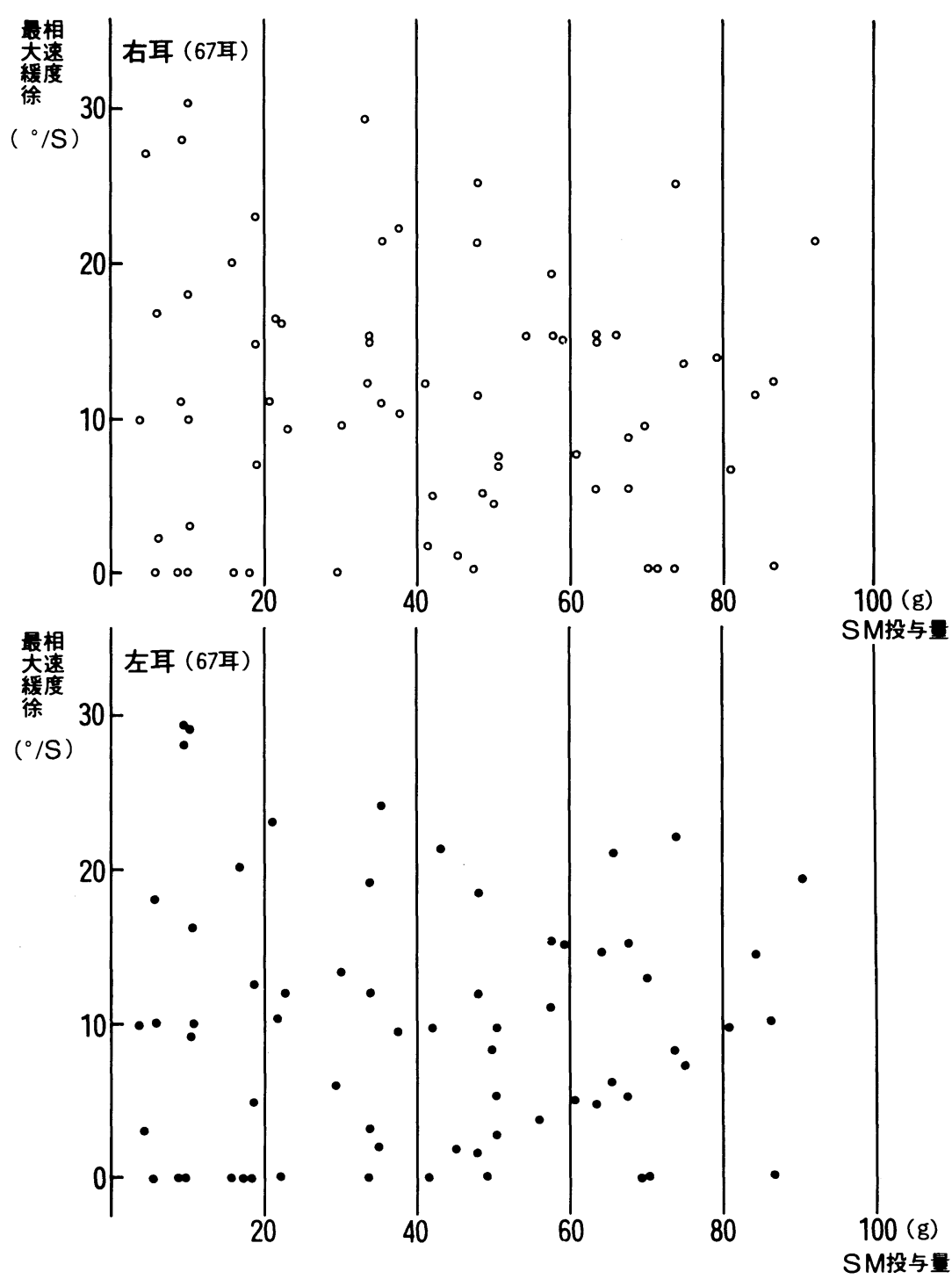

図 1 S M 投与量と温度眼振検査 
検査を施行した 68 名中 7 名に両側前庭機能高度 低下を認めた。これら 7 名は，いずれも歩行 時, 眼前の風景が上下あるいは水平方向に摇れ て歩けないなどの固視歩行障害を訴えた Jumbling 症例であった. これら 7 名中で追跡検查 を行らことのできた 5 名の体平衡の回復を主体
とした Vestibular compensation について立ち 直り検査, 重心動摇検査, 温度眼振検査, 視運 動性眼振検査を用いて 経過観察を行った（表 6 ). 各症例とも Jumbling 発症直後は介助な しでは，起立歩行がまったく行えない状態であ った. 温度眼振検查は ice water で両側無反

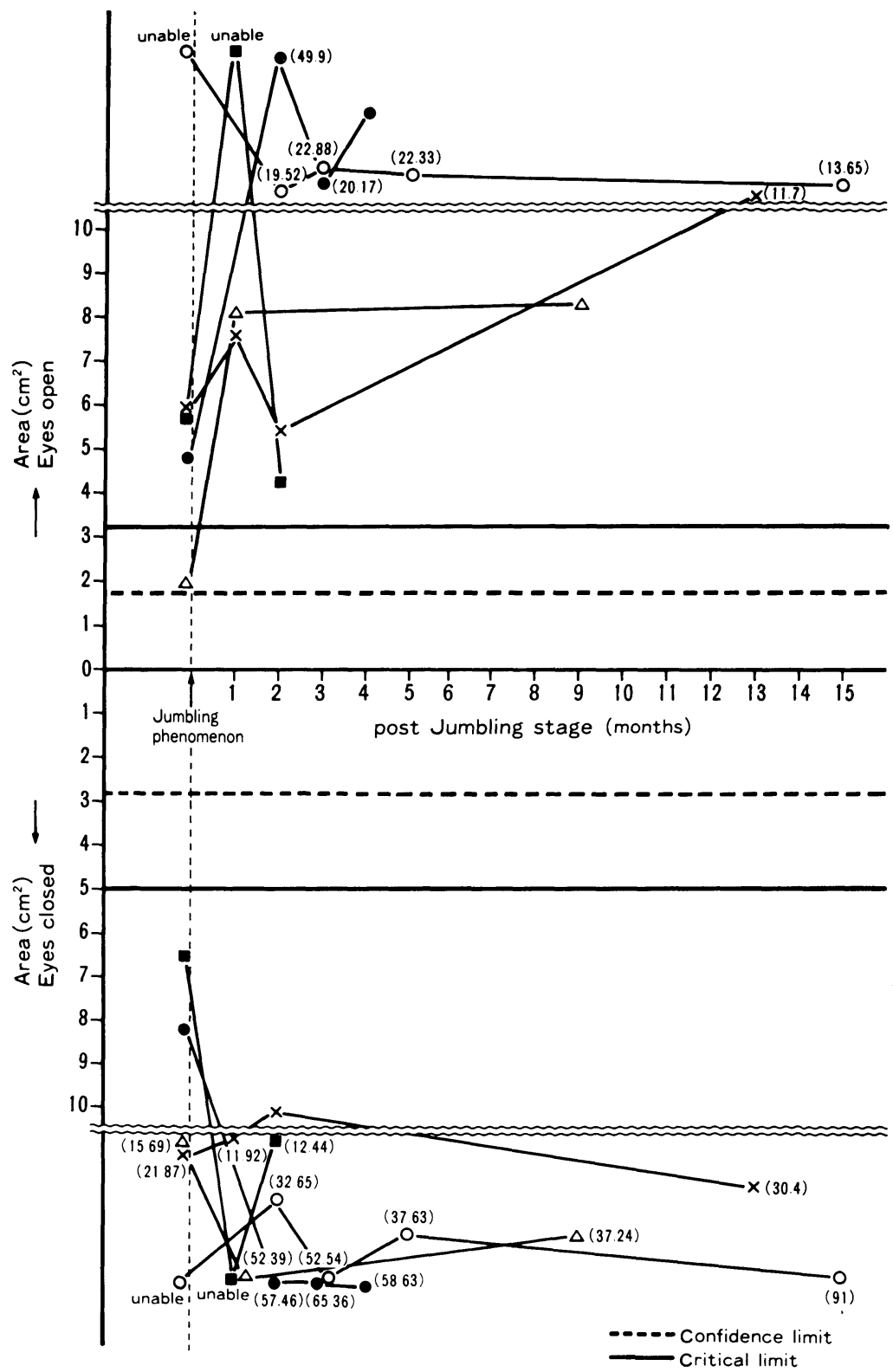

図 2 Jumbling 5 症例の重心動摇 
応で, 立ち直り検査, 重心動摇検査は開眼閉眼時 とも施行不可能であった，視運動性眼振検査は 全例正常であった，各症例における経過観察期 間は症例 $1: 4$ ケ月, 症例 $2: 13$ ケ月, 症例 3 : 2 ケ月, 症例 $4: 15$ ケ月, 症例 $5: 10$ ケ月と さまざまであるが，最終検査の時点で全例に括
いて温度眼振検査は両側無反応であった。立ち 直り検査については，症例 $1 ， 2 ， 3 ， 4$ では 開眼時の両脚起立が可能となり, 症例 5 では, 開眼閉眼時ともに両脚起立が可能な状態であっ た.これら 5 症例の重心動摇検査の結果を Jumbling 発症時から経過を追って記録した. 図 2

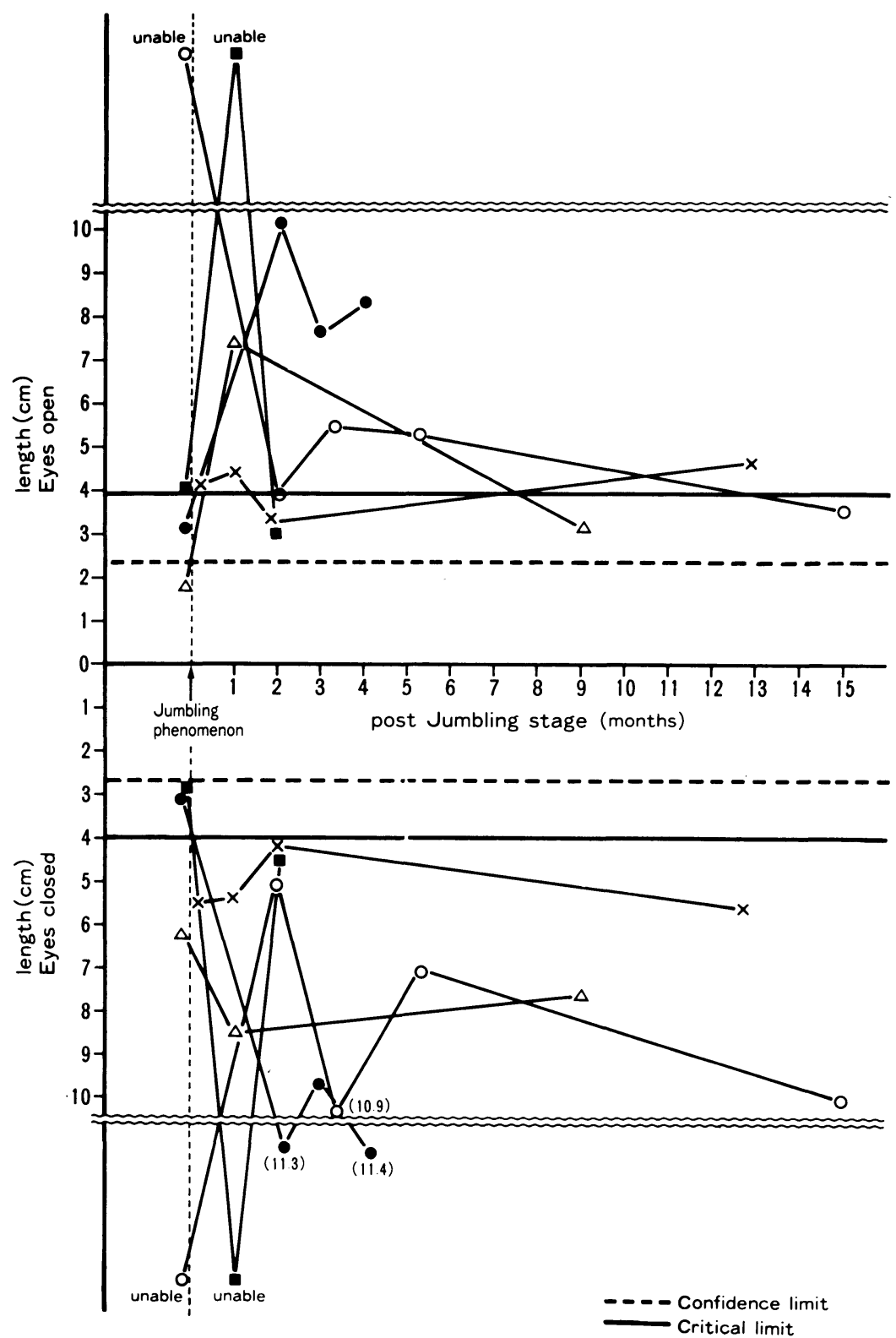

図 3 Jumbling 5 症例の前後動摇 
は Jumbling 発症直後からの動摇面積の経過を 追ったものであるが，全例において，開眼閉眼 時ともに棄却限界を大きく，逸脱している。 こ の傾向は時間経過（2ケ月〜15ケ月）にもかか わらず，依然として見られ閉眼時では，時間経 過につれて動摇面積が大きくなり，棄却限界か
ら遠ざかる傾向が見られた。

図 3 には前後動摇を示したが，開眼時では動 摇がやや改善されているが，閉眼時には時間経 過と無関係に動摇が増大している。図 4 は，同 様に Jumbling 5 症例の左右動摇を示したもの であるが，開眼時は前後動摇と同じく，動摇の

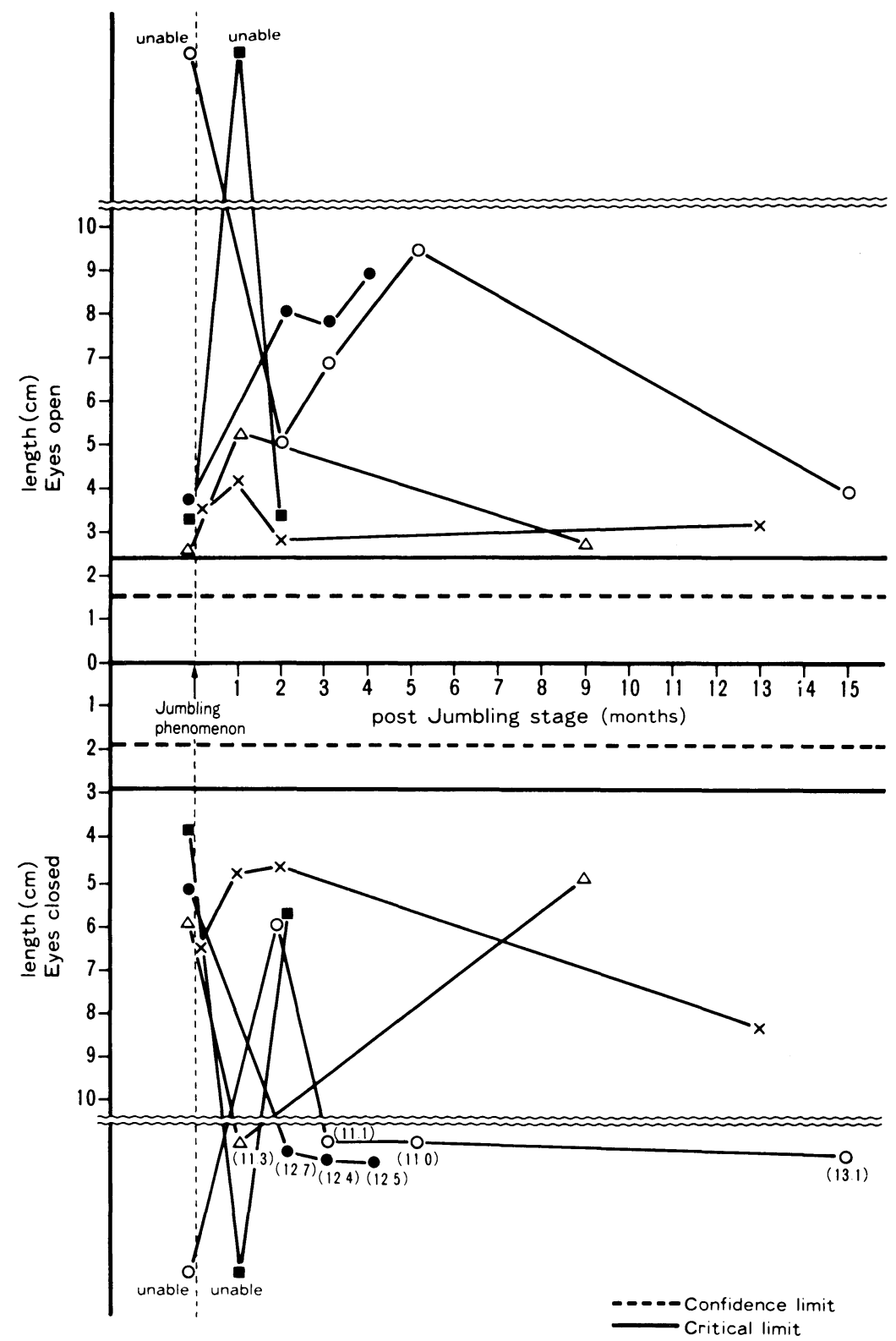

図 4 Jumbliing 5 症例の左右動摇 


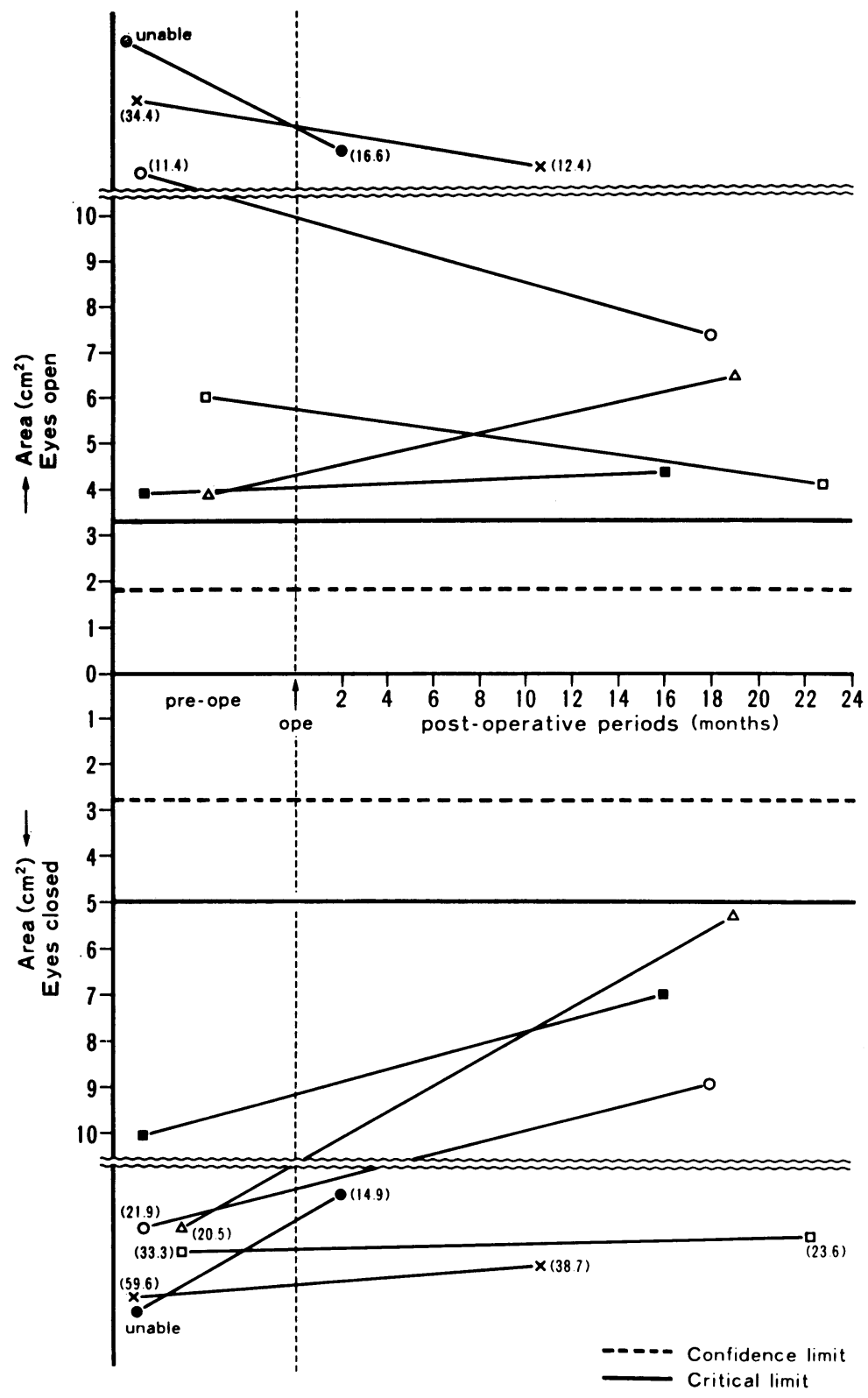

図 51 側前庭機能低下 6 症例の動摇面積 


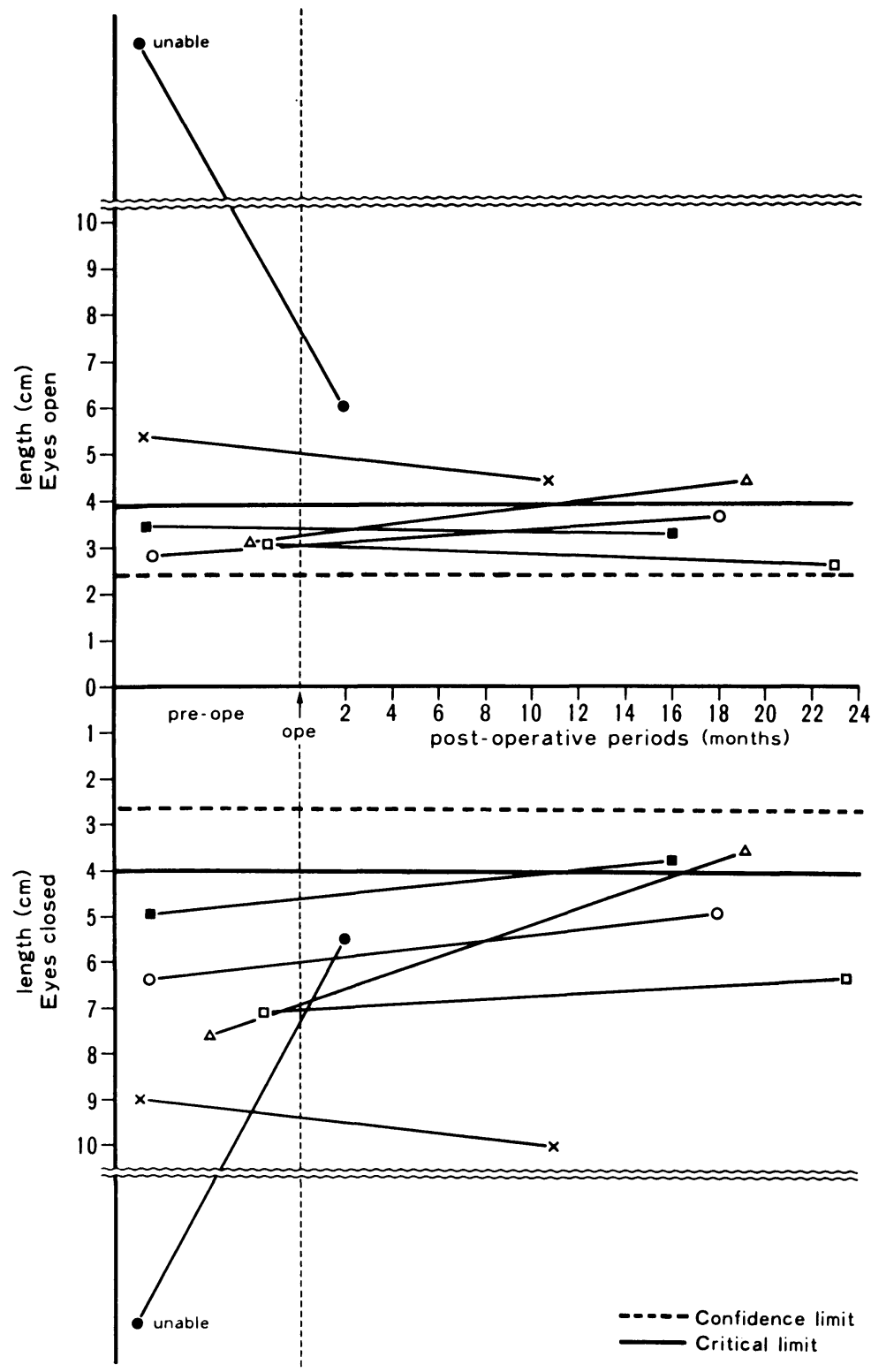

図 61 側前庭機能低下 6 症例の前後動摇 


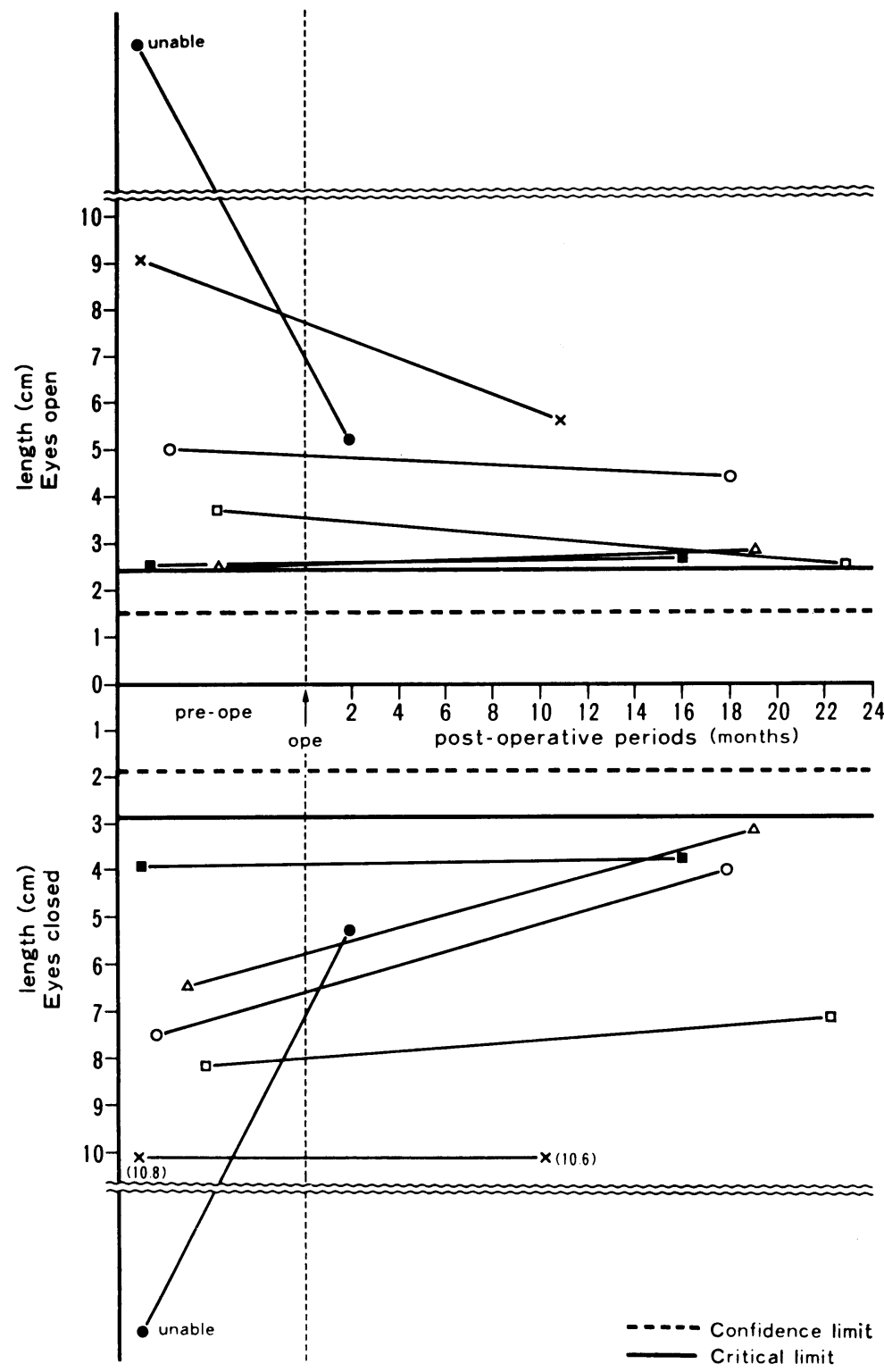

図 7 1 側前庭機能低下 6 症例の左右動摇 
表 71 側前庭機能低下症例

\begin{tabular}{|c|c|c|c|c|c|c|c|}
\hline $\begin{array}{l}\text { Number } \\
\text { of cases }\end{array}$ & age & $\operatorname{sex}$ & $\begin{array}{l}\text { Kinds of } \\
\text { brain tumor }\end{array}$ & tumor size & $\begin{array}{l}\text { post-operative } \\
\text { periods } \\
\text { (months) }\end{array}$ & 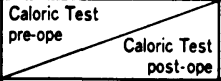 & $\begin{array}{l}\text { OKN } \\
\text { pre-ope } \\
\text { post-ope }\end{array}$ \\
\hline 1 & 51 & q & $\begin{array}{l}\text { rt. } \\
\text { acoustic } \\
\text { neurinoma }\end{array}$ & $2 \times 2.5 \times 2$ & 2 & & \\
\hline 2 & 20 & ㅇ & $\begin{array}{l}\mathbf{l t} \\
\text { acoustic } \\
\text { neurinoma }\end{array}$ & $5 \times 4.5 \times 3.5$ & 11 & & \\
\hline 3 & 44 & $\delta$ & $\begin{array}{l}r t . \\
\text { acoustic } \\
\text { neurinoma }\end{array}$ & $1 \times 1 \times 1$ & 16 & & \\
\hline 4 & 57 & $\delta$ & $\begin{array}{l}\boldsymbol{\ell} \text { t. } \\
\text { trigeminal } \\
\text { neurinoma } \\
\end{array}$ & $5 \times 4 \times 4$ & 18 & & \\
\hline 5 & 42 & $\delta$ & $\begin{array}{l}\mathrm{rt} . \\
\text { trigeminal } \\
\text { neurinoma }\end{array}$ & $4 \times 3 \times 3$ & 19 & & \\
\hline 6 & 73 & $q$ & $\begin{array}{l}\mathrm{rt} . \\
\text { acoustic } \\
\text { neurinoma }\end{array}$ & $3 \times 4 \times 3$ & 23 & & \\
\hline
\end{tabular}

$\mathrm{N}$ : normal AN : abnormal AN : abnormal but almost the same as AN

大きさが改善されているが閉眼時には, 動摇が 大きくなり時間経過にもかかわらず，改善傾向 は認められなかった。

以上今回我々が経験した Jumbling 5 症例 （両側前庭機能高度低下）では，視性代償の影 響が若干らかがわれるが，体平衡の回復を主体 とした Vestibular compensation は認められ なかった. 次に両側前庭機能高度低下例と比較 するために, 1 側前庭機能低下症例 6 例の重心 動摇検查結果を，時間経過を追って検討した。

対象は表 7 の如くで，いずれも小脳橋角部腫瘍 （三叉神経腫瘍 2 名, 聴神経腫瘍 4 名）のため 1 側前庭機能低下をきたしており, 全例腫瘍摘 出術を施行している. 術前, 立ち直り検査は開 眼閉眼時ともに全例において施行不可能であっ たが，術後（2ケ月〜 3 ケ月）開眼時の立ち直 り検査はほぼ正常範囲に回復した。

\section{考}

Jumbling 現象は雨側高度前庭機能低下もし くは，衰失時に出現する身体頭部動摇視および 固視障害で(1)2), 1941年 Dandy が，メニエル氏 病に対する外科治療として両側前庭神経を切断 し，その後に現われた重篤な障害を Jumbling
温度眼振検查（冷温交互法）については，術 前 4 例が両側前庭機能低下を示しているが， ち 2 例は術後, 1 側前庭機能低下となり 2 例が 不変であった。他の 1 例は, 術前術後ともに 1 側前庭機能低下を示した．残り 1 例は, 術前 1 側前庭機能低下を示したが術後, 両側前庭機能 低下をきたした。視運動性 眼振検査について は, 術前, 4 例が正常で, 2 例に異常を認めた が，術後も特に変化は，見られなかった。

以上の 1 側前庭機能低下症例 6 例の重心動摇 検查結果を時間経過を追って示すと図 5，6， 7 の如くであった. 動摇面積, 前後動摇, 左右 動摇が術前では, 6 例全例で, 開眼, 閉眼時と もに，棄却限界をこえる異常值を示している が，術後，開眼閉眼時ともに信頼限界へ近づく 傾向が見られた.この傾向は開眼時に特に著明 であった。

\section{察}

of object として報告したのが最初とされている. その後, この現象は Meyor Zum Gottesberge, ついで Jatho により取りあげられ典型的には, 両側迷路機能廃絶例でみられるが，1 側迷路機 能廃絶例でも, 程度は軽いが完全な代償に至る 
以前に発現し得ることが明らかにされている ${ }^{3)}$ Jumbling 現象については, 本邦では, 1967年 以降，アミノ配糖体系抗生㓮（硫酸 SM, GM, KM）による内耳障害との関連で，種々報告さ れている，今回，我々は SM 使用者に対して 定期的に平衡機能検查を施行し, Jumbling 7 症例を経験した。 このらち追跡検査が可能であ った 5 症例について，立ち直り検査（Rombe$\mathrm{rg}$, Mann 単脚起立), 重心動摇検査, 温度眼 振検査, 視運動性眼振検査を用いて体平衡の回 復を主体とした Vestibular compensation の， 検討を行い，以下の結果を得た。1）温度眼振 検查 (ice water 刺激): 両側無反応, 2 ) 立 ち直り検查：1 例で両脚起立が開眼, 閉眼時と もに可能. 他の 4 例では開眼時の両脚起立のみ が可能. 3) 重心動摇検査：動摇面積, 前後動 摇, 左右動摇ともに棄却限界をこえる異常值を 示し，時間経過にもかかわらず改善傾向はみら れなかった。 むしろ，閉眼時には動摇が時間経 過につれて増大する傾向が見られた。

これらのことより，観察期間は 2 ケ月〜15ケ 月と短いが，両側前庭 機能高度低下例では， vestibular compensation が非常に起りにくい ことが，推察できる(4)5)6). Jumbling 症例の予 後について, 亀井 ${ }^{3)}$ は, Jumbling 現象を呈し た両側前庭神経炎で, 温度眼振反応の改善後, 少 し遅れて Jumbling 現象の軽快をみた 1 症例を 報告し，迷路機能に残存のある場合，Jumbling は完全消失が期待できると推察している。一 方, 宮田 ${ }^{7)}$ らは, 温度眼振反応が回復し, それ と同時に固視障害が回復した 4 例及び，温度眼 振反応は変化しないが，固視障害が回復した 1 例を報告し，発症 1 年位まで，回復する例もあ ると述べている，又，天岸は，回転検査，温度 眼振検査による反応が回復した SM 中毒 3 症 例を報告している.

桶渡 ${ }^{1)}$ らは, Jumbling 22症例中, 9 症例の 経過観察を行い， 7 例に改善傾向を認めてお り，温度眼振検査で高度反応低下の屯ま，もし くは変化のないものまで, Jumbling 現象の改
善を認めたことより，半規管系と耳石系の間に 回復の差がある, あるいは, 両系に対する中枢 の代償性に差があるのではないかと推察してい $ろ^{9)}$.

我々の 5 症例では, 全例, 温度眼振検査は, ice water 刺激で無反応であった.

しかし, Jumbling 症状については, 1 例で 改善傾向が見られ，他の 4 例では，Jumbling 症状の消失はないままで, 自覚的な慣れを生じ て㧍り，患者自身が具合いの悪い体動をさける ことにより，起立歩行が可能な状態となってい $ろ^{10) 11)}$.

更に今回，我々は Jumbling 症例（両側前庭 機能高度低下症例）の Vestibular compensation と比較するために，小脳橋角部腫瘍により 1 側前庭機能低下をきたした 6 症例の, 術前術 後の体平衡の回復について, 経過観察を行い, 以下の結果を得た.

1) 温度眼振検査 (冷温交互法)：2 例で改善, 4 例は不変，2）立ち直り検査：全例に打い て, 開眼時の立ち直り検查は正常に回復した。

3 ）重心動摇検査: 開眼時の動摇面積, 前後動 摇, 左右動摇は信頼限界へ大きく近づく傾向を 示した.

これらの結果は, 1 側前庭機能低下後, 生じ た Vestibular compensation を示唆している. これを先程の Jumbling 症例（両側前庭機能高 度低下）と比べてみると，Vestibular compensationの起り方に大きな違いがある.

すなわち， 1 側前庭機能低下症例では，発 症後 2 ケ月〜23ケ月で, 開眼時の Vestibular compensation が見られるが，両側前庭機能高 度低下症例では, 発症後 2 ケ月〜15ケ月を経過 しても, 開眼時の Vestibular compensation が みられないだけでなく, 閉眼時では体平衡の障 害が，増強する傾向を示している.

このことは，いわゆるVestibular compensationが生じるためには, 少なくとも, 軽度では あっても， 1 側の前庭機能の残存が必要である ことを示唆している. 


\section{ま と め}

68名の SM 使用者に定期的に平衡機能検査を施行して 7 名の Jumbling 症例を経験した. この 7 名中，追跡検查可能であった 5 名につき体平衡の回復を主体とした，Vestibular compensation について経過観察を行った.

さらに Jumbling 症例（両側前庭機能高度低下）と比較するため小脳橋角部腫瘍により 1 側前庭 機能低下をきたしたもの 6 名についても Vestibular compensation に関して同様の経過観察を行 った. その結果, 1 側前庭機能低下症例では, 開眼時の立ち直り検查の正常範囲への回復, 重心動 摇検查結果（開眼・閉眼時）の改善などVestibular compensation を示唆する 所見を認めた。し かし Jumbling 症例では, 立ち直り検査, 重心動摇検査ともに改善傾向は認められなかった.

このことょり，Vestibular compensation が生ずるには，少なくとも軽度ではあっても，1側の 前庭機能の残存が必要ではないかと考えられる.

\section{文献}

1）樋渡章二, 他 : Jumbling 22症例. 耳鼻臨床 75 : 1979. $230 \sim 236,1982$.

2 ）梅田悦生, 他 : 薬物 中毒によるめまい. 平衡障 害. 耳鼻臨床 69:229～235, 1976.

3 ）亀井民雄, 他 : Jumbling について. 耳鼻臨床 77 : 566 574, 1984.

4 ) 時田 喬, 他 : 迷路反応言失例の平衡機能の観察 一ヒトの迷路機能に対する考察一. Equilibrium Res $37: 19 \sim 26,1978$.

5 ) 時田 喬, 他: 迷路性立ち直り反射の 動特性. Equilibrium Res 38: 23〜28, 1979.

6 ）時田 喬, 他 : 頭部並びに重心動摇記録計による 立ち直り反射検査. 耳鼻臨床 $65: 443 \sim 456$, 1972.

7 ）宮田英雄，他 : アミノ配糖体系抗生剂投与による 平衡障害症例. Equilibrium Res 38: $260 \sim 268$,

8 ）天岸太郎：前庭神経麻痺を惹起させる streptomycin 中毒の 3 例. 耳喉 $24: 335 \sim 337,1952$.

9 ) 森中節子, 他 : 両側温度眼振岥失を来たした硫酸 ストレプトマイシン中毒の 1 例. 耳鼻臨床 73 : $791 \sim 802,1980$.

10）水越鉄理, 他：髄膜炎後にみられた両側前庭機能 高度低下例 (Jumbling 現象). 耳鼻臨床 75 : 225 259, 1982.

11）細見英男, 他：ストレプトマイシン・カナマイシ ン投与による眩暈症例. 耳鼻臨床 $66: 289 \sim 296$, 1973.

$$
\left(\begin{array}{l}
\text { 別刷請求先 : 桜井敏恵 } \\
\text { 干545 大阪市阿倍野区旭町1-5-7 } \\
\text { 大阪市立大学医学部耳鼻咽喉科学教室 }
\end{array}\right)
$$

